УДК 343.01

DOI https://doi.org/10.32849/2663-5313/2020.4.49

\title{
Микола Гуиуляк,
}

канд. юрид. наук, дочент,

доцент кафедри кримінально-правових дисииплін

та оперативно-розшукової діяльності

Прикарпатського факультету

Начіональної академії внутрішніх спрае

\section{Анастасія Лакіза,}

курсант 403 навчальної групи

Прикарпатського факультету

Начіональної академії внутрішніх спрае

\section{РЕТРОСПЕКТИВНИЙ АНАЛІЗ ВИЗНАЧЕННЯ ПОНЯТТЯ ПОВТОРНОСТІ ЗЛОЧИНІВ ЯК ВИДУ МНОЖИННОСТІ}

Більшість труднощів, з якими стикаються правоохоронні органи та суди під час кримінально-правової кваліфікачії, зокрема кваліфікачї повторності злочинів, викликані недосконалістю і суперечністю чинного законодавства. Скажімо, між нормами, які визначають поняття «повторність злочинів», «сукупність злочинів» та «речидив злочинів», виникли певні колізї. Як наслідок, ні в науці кримінального права, ні у правозастосовній практичі немає однозначних відповідей щодо кримінально-правової очінки вчинення особою декількох посягань. Водночас у кримінальному кодексі Украйни не визначено, як здійснювати кваліфікачію повторності злочинів і якими правилами при ивому керуватися. Різні підходи до кваліфікачії таких злочинів було запропоновано у постановах Пленуму Верховного Суду Украйни в юридичній літературі та інших нормативно-правових актах. Це, зі свого боку, призводить до помилок у кваліфікаиіі злочинів, порушення прав і свобод громадян на стадіях досудового та судового слідства, а також під час призначення покарання. На сучасному етапі розвитку кримінального права значний внесок у вирішення проблем кримінально-правовоі характеристики множинності, зокрема повторності? злочинів зробили такі украйнські вчені, як: О. О. Дудоров, І. О. Зінченко, О. В. Ільїна, М. Й. Коржанський, В. В. Кузнєцов, О. К. Марін, М. І. Мельник, В. О. Навроиький, А. В. Савченко, Т. І. Созанський, А. А. Стрижевська, В. I. Тютюгін, П. Л. Фріс, M. I. Хавронюк. Однак окремі аспекти визначення правил кваліфікачї̈ повторності злочинів залишаються дискусійними. Водночас спостерігається відсутність єдиних чітко сформульованих правил кваліфікаиії повторності злочинів та фрагментарний характер їх дослідження. Нині, відповідно до Указу Президента України від 07 серпня 2019 року № 584/2019, робочою групою з питань розвитку кримінального права готуються пропозиції стосовно внесення змін до законодавства про кримінальну відповідальність, а саме прийняття нової редакиії Кримінального кодексу України. Питанням особливостей кримінально-правової кваліфікації науковиями приділяється особлива увага, а оприлюднені позииї̈ засвідчують той факт, що нормативно-визначені основи в частині кваліфікаиії знайдуть своє закріплення в окремих статтях відповідної книги. Окрім иього, власне правила кваліфікації множинності злочинів (повторність, сукупність, рецидив) пропонується нормативно закріпити, а не розглядати їх тільки у доктрині.

Ключові слова: кримінально-правова характеристика, досудове розслідування, повторність злочинів, множинність, рецидив, тотожні та однорідні злочини, кримінально-правова характеристика, кваліфікація.

Постановка проблеми. У період реформування національного законодавства України, 3 прийняттям нового Кримінального процесуального кодексу України, значно змінився порядок здійснення всього кримінального провадження. Проблемними аспектами, 3 якими стикаються правоохоронні органи, є неоднакове застосування норм права відповідно до КК України, оскільки говорити нині про досконалість чинного кримінального та кримінально-процесуального законодавства ми не можемо, адже існує багато розбіжностей, які у правозастосовній практиці і породжують численні колізії. Наша наукова праця присвячена історичним та порівняльно-правовим аспектам 
становлення інституту множинності у кримінальному законодавстві та доктрині з метою визначення змісту такого виду множинності, як повторність злочинів.

Аналіз останніх досліджень і публікацій. Окремими аспектами дослідження інституту множинності злочинів приділяли значну увагу у своїх працях такі науковці, як: О. О. Дудоров, І. О. Зінченко, О. В. Ільїна, М. Й. Коржанський, В. В. Кузнєцов, О. К. Марін, М. І. Мельник, В. О. Навроцький, А. В. Савченко, Т. І. Созанський.

Метою статті є ретроспективний аналіз розвитку інституту повторності злочинів з метою удосконалення чинного законодавства та усунення колізій під час здійснення кваліфікації.

Виклад основного матеріалу. Для того щоб зрозуміти сучасний стан розвитку законодавства в будь-якій галузі, слід використовувати історію його встановлення. Цей розвиток був спрямований на дослідження кримінальної відповідальності та покарання і пройшов досить складний шлях. Видатний дослідник історії науки Б. Кедров писав: «Вивчення минулого може і має слугувати засобом для того, щоб зрозуміти сучасне і передбачити майбутнє» [2, с. 78]. Дослідження зазначеного питання зумовлюється багатьма факторами, а саме: відсутністю теоретичних знань, нестійкою судовою практикою кримінально-правового регулювання у сфері захисту суспільства від окремих видів злочинів; відсутністю досвіду щодо узагальнення повторності злочинів.

Потрібно проаналізувати історичний та порівняльно-правовий аналіз кримінального законодавства 3 метою визначення особливостей множинності злочинів загалом та їх повторності зокрема.

Яскравим прикладом $є$ те, що правоохоронні органи та суди під час кримінально-правової кваліфікації, зокрема й кваліфікації повторності злочинів, стикаються 3 такою проблемою, яка спричинена суперечностями чинного законодавства. У науці кримінального права, яка застосовується у практичній діяльності, немає однозначних відповідей щодо кримінально-правової оцінки дії, яку вчиняе особа щодо певного посягання

У кримінальному законі не визначено, як здійснювати кваліфікацію повторності злочинів і якими правилами при цьому керуватися.

Проаналізувавши історію кримінального законодавства, можна сказати, що дане питання розглядалося в багатьох трактатах, грамотах, судебниках, але при цьому мало різне значення.
Вважається, що першою писаною пам'яткою звичаєвого права у добу існування Руської держави стала «Руська правда», багато учених розглядали іiі тлумачення, однак кожен дотримувався своєї думки, також її вивчали і стосовно повторності злочинів. Дана пам'ятка відображала такий етап розвитку держави і права, який ще не давав можливості говорити про повторність чи іншу форму множинності злочинів.

Злочинна повтореність також згадується в епоху уставних грамот і судебників, які широко застосовувались на теренах України, були побудовані на її нормативній базі. У них описувалося, що повторність злочинів слід розуміти як вчинення особою двох чи більше злочинів, за один з яких вона вже підлягала покаранню або була засуджена відповідно до закону [6, с. 478].

31864 року діяв ще один нормативний акт кримінально-правового характеру «Статут про покарання, що накладаються мировими суддями» (далі - Статут). Однак укладачі цього Статуту повторення злочинних діянь визначили по-іншому. Так, у п. 3 ст. 14 вказано, що повторенням є повторення того ж або абсолютно однорідного проступку до закінчення року після призначення покарання [3, с. 109].

Отже, проаналізувавши даний Статут, можна сказати, що він містив лише спеціальне повторення, виключаючи загальне. Зі сказаного випливає, що Статут визначив не відбування покарання, а призначення покарання.

Повторність злочинів також розглядали російські криміналісти як один з елементів, який характеризує суб’єктивну сторону злочину (волю злочинця), оскільки у дореволюційній літературі вважалося, що особа, яка вчинила повторний злочин із проявом злої (неконтрольованої) волі, схильна до вчинення злочину.

Про особливу злісну волю особи свідчило вчинення тотожних чи однорідних злочинів, відбуття частини чи всього покарання або засудження особи за попередній злочин, зв'язок злочинів за часом. Водночас характер повторних злочинів учені не визначили. Не було запропоновано і строків давності між попереднім і повторним злочином [7].

Значний вплив на кримінальне законодавство України щодо вирішення проблем кримінально-правової характеристики множинності, а саме повторності, злочинів справили у своїх працях українські вчені, зокрема : О. В. Ільїна, М. Й. Коржанський, О. Дудоров, I. О. Зінченко. Проте їхні праці стосувалися переважно визначення понять повторності злочинів, відмежування повторності злочинів від суміжних понять. 
Також, опрацювавши їхні роботи, можна говорити про відсутність чітко сформульованих правил повторності злочинів та уривчастий характер їх дослідження.

Отже, ситуація, яка склалася в законодавстві, науці та правозастосовній практиці, засвідчує необхідність та своєчасність проведення комплексного дослідження проблем кваліфікації повторності злочинів.

На сучасному етапі розвитку кримінального права в КК України, а саме в Розділі VII Загальної частини КК (ст. 32-35 КК), закріплено повторність, сукупність і рецидив злочинів. У Загальній частині КК України визначено поняття повторності злочинів та окреслено її наслідки. В Особливій частині КК України повторність у більшості статей виступає кваліфікованою ознакою складу злочину і впливає на кваліфікацію вчиненого злочину [4, с. 32-35].

Наприкінці XIX - на початку XX ст. під повторністю розуміли вчинення декількох злочинів, які можуть бути тотожними, однорідними та різнорідними. Розвиток кримінального законодавства радянської епохи створив передумови для сучасного стану нормативного регулювання повторності злочинів.

Так, повторністю злочинів визнається вчинення двох або більше злочинів, передбачених тією самою статтею або частиною статті Особливої частини Кримінального Кодексу України. При цьому ч. 1 та ч. 3 цієї статті КК визначають певні особливості злочинів, що можуть утворювати повторність, ч. 2 відмежовує повторність злочинів від одиничного продовжуваного злочину, а ч. 4 встановлює особливі кримінально-правові аспекти, за яких повторність відсутня. На наявність повторності також не впливае факт вчинення відповідних злочинів одноосібно чи у співучасті [4, с. 32].

Враховуючи думки, викладені в літературі, а також на підставі власного аналізу можна виділити такі ознаки, які виражають кримінально-правовий зміст повторності злочинів: повторність утворюють два і більше злочини; збереження кримінальноправового значення хоча б двома злочинами, що утворюють повторність; вчинення двох і більше злочинів неодночасно.

Поняття повторності злочинів у кримінальних кодексах більшості пострадянських держав містить такі ознаки: вчинення особою двох або більше злочинів, передбачених однією і тією самою статтею чи частиною статті, передбачених різними статтями або частинами статті; повторність має місце незалежно від того, чи був суб'єкт засуджений за раніше вчинений злочин.
Слід сказати, що це ознаки множинності злочинів загалом і такі ж ознаки випливають із нормативного визначення поняття повторності злочинів, передбаченого ст. 32 КК України. Це підтверджує тезу про те, що поняття повторності злочинів і поняття множинності злочинів позначають одне і теж явище - вчинення декількох злочинів [5, с. 82].

У КК пострадянських держав можна виділити і позитивні моменти, які можна враховувати для вдосконалення питання множинності злочинів, зокрема повторності злочинів, в українському кримінальному законодавстві: законодавчу характеристику одиничних злочинів як структурних елементів повторності злочинів (Грузія, Узбекистан, Казахстан, Латвія), закріплення певних правил кваліфікації повторності злочинів (Казахстан, Латвія).

У більшості кримінальних кодексів європейських держав повторність злочинів розглянуто лише в контексті призначення покарання. Не наведено поняття повторності злочинів і не визначено правила кваліфікації повторності злочинів. До недавнього часу повторність злочинів визнавалася множинністю в кримінальному законодавстві. Однак її існування тривалий час викликало критичні зауваження у зв'язку з відсутністю вирішення комплексу проблем, що виникали під час функціонування цього кримінальноправового інституту [1, с. 65]. Аналогічна ситуація існує і у вітчизняному законодавстві, оскільки вчинення особою двох або більше злочинів може за відповідних умов утворювати сукупність і повторність або повторність і рецидив.

Виключення із законодавства окремих держав повторності злочинів не спричинило позитивних зрушень у протидії злочинності, a, навпаки, послабило заходи кримінальноправового впливу.

\section{Висновки}

Отже, найбільш оптимальним варіантом вирішення проблем повторності злочинів у КК України є розробка науково обгрунтованих критеріїв відмежування цієї форми множинності злочинів від сукупності та рецидиву. У зв'язку з цим пропонуємо повторністю злочинів визнавати насамперед вчинення особою тотожних злочинів. Однорідні ж злочини слід вважати повторними лише у разі, коли така повторність безпосередньо передбачена у статтях КК України. Решта однорідних злочинів $є$ виключно сукупністю злочинів. Крім того, слід підтримати пропозицію відносити до повторних лише злочини, за які особу не було засуджено. 
Проаналізувавши вищевикладене, можна сказати, що законодавство щодо повторності злочинів, яке було спрямовано на дослідження кримінальної відповідальності, і здобуті знання щодо історії цього питання слід застосовувати в навчально-практичній діяльності, а ситуація, яка склалася в законодавстві, доктрині та правозастосовній практиці, засвідчує необхідність та своєчасність проведення комплексного дослідження проблем кваліфікації повторності злочинів, особливо щодо спеціального виду повторності.

\section{Список використаних джерел:}

1. Агаєв І. Б. Проблема повторності в кримінальному праві. Москва : Юрист. 2004. С. 157.
2. Кедров Б. М. Історія науки и принципи їі дослідження. Питання філософії. 1971. № 9. С. 78.

3. Коваленко О. Вісник Киівського начіонального університету імені Тараса Шевченка. Юридичні науки. 2011. Вип. 89. С. 107-111.

4. Кримінальний кодекс України. Чинне законодавство із змінами та допов. на 05 вересня 2017 року. Київ : Алерта. 2017. С. 208.

5. Навроцький В. О. Основи кримінально-правової кваліфікації : навчальний посібник. 2-ге вид. Київ : Юрінком Інтер. 2009. С. 512.

6. Таганцев Н. С. Русское уголовное право. Общая часть. СПб. : Гос. Тип. 1902. С. 823.

7. Устрицька Н. І. Кваліфікація повторності злочинів : монографія. Львів: Львівський державний університет внутрішніх справ, 2013. C. 216.

Most of the difficulties that law enforcement agencies and courts face in criminal law qualifications, including qualifications for the repetition of crimes, are caused by the imperfection and inconsistency of the current legislation. Say, between the norms that define the concept of "repetition of crimes", "totality of crimes" and "recidivism", certain conflicts arose. As a result, neither in the science of criminal law, nor in law enforcement practice there are unequivocal answers on the criminal law assessment of a person committing several attacks. At the same time the Criminal Code of Ukraine does not specify how to qualify the repetition of crimes and what rules to be guided with. Various approaches to the qualification of such crimes were suggested in the decisions of the Plenum of the Supreme Court of Ukraine in the legal literature and other legal acts. In its turn it leads to errors in the qualification of crimes, violation of rights and freedoms of citizens at the stages of the pre-trial and judicial investigation as well as in sentencing. At the present stage of the development of the criminal law a significant contribution to solving the problems of the criminal and legal characteristics of the multiplicity, in particular the repetition of the crimes has been made by the Ukrainian scientists, namely: O.O. Dudorov, I.A. Zinchenko, A.V. Ilyina, M.I. Korzhansky, V.V. Kuznetsov, A.K. Marin, M.I. Melnik, V.A. Navrotsky, A.V. Savchenko, T. Sozansky, A.A. Strizherskaya, V.I. Tyutyugin, P.L. Fris, M.I. Havronyuk. However, some aspects of defining the rules of qualification for repeated crimes remain debatable. At the same time there is a lack of the clearly formulated rules for qualifying the recurrence of crimes and the fragmented nature of theirresearch. Currently, in accordance with the Decree of the President of Ukraine of August 7, 2019 No. 584/2019, the working group on the development of criminal law is preparing proposals to amend the legislation on criminal liability, namely, the adoption of a new version of the Criminal Code of Ukraine. The issue of peculiarities of criminal qualification by scientists is given special attention, and the published positions testify to the fact that normative-determined bases in terms of qualification will find their consolidation in separate articles of the relevant book. In addition, the very rule of qualification of a multitude of crimes (repetition, aggregate, recidivism) is proposed to be legally enshrined, and not considered only in doctrine.

Key words: criminal and legal characteristics, pre-trial investigation, repetition of crimes, plurality, relapse, identical and homogeneous crimes, criminal and legal characteristics, qualification. 